\title{
The southernmost foci of Dermacentor reticulatus in Italy and associated Babesia canis infection in dogs
}

\author{
Emanuela Olivieri ${ }^{1}$, Sergio A. Zanzani ${ }^{2}$, Maria S. Latrofa ${ }^{3}$, Riccardo P. Lia ${ }^{3}$, Filipe Dantas-Torres ${ }^{3,4}$,
} Domenico Otranto ${ }^{3}$ and Maria T. Manfredi ${ }^{*}$

\begin{abstract}
Background: Two clustered clinical cases of canine babesiosis were diagnosed by veterinary practitioners in two areas of northeastern Italy close to natural parks. This study aimed to determine the seroprevalence of babesial infection in dogs, the etiological agents that cause canine babesiosis and the potential tick vector for the involved Babesia spp.

Methods: The study area was represented by two parks in northeastern Italy: Groane Regional Park (Site A) and the Ticino Valley Lombard Park (Site B). From March to May 2015 ticks were collected from the vegetation in three transects in each site. In the same period, blood samples were collected from 80 dogs randomly chosen from veterinary clinics and kennel located in the two areas. Morphological identification of the ticks was performed and six specimens were molecularly characterised by the amplification and sequencing of partial mitochondrial 125 rRNA, $16 \mathrm{~S}$ rRNA and cox1 genes. For phylogenetic analyses, sequences herein obtained for all genes and those available from GenBank for other Dermacentor spp. were included. Dog serum samples were analysed with a commercial indirect fluorescent antibody test to detect the presence of $\mathrm{gG}$ antibodies against Babesia canis. Ticks and blood samples were tested by PCR amplification using primers targeting $18 \mathrm{~S}$ rRNA gene of Babesia spp.

Results: Ticks collected $(n=34)$ were morphologically identified as adults of $D$. reticulatus. Twenty-eight ticks were found in all transects from Site A and the remaining six were collected in Site B. Blast analysis of mitochondrial sequences confirmed the morphological identification of processed tick specimens by revealing a highest nucleotide similarity (99-100 \%) with those of D. reticulatus available in the GenBank database. The phylogenetic trees were concordant in clustering D. reticulatus in a monophyletic clade. Seven dogs (8.8 \%) had antibodies against $B$. canis, most of which $(n=6)$ came from Site A. Analysis of nucleotide sequences obtained from one tick and from one dog identified B. canis displayed a $100 \%$ similarity to those available in GenBank.
\end{abstract}

Conclusions: This study morphologically and molecularly confirms the presence of D. reticulatus in Italy and links it, for the first time, with the occurrence of $B$. canis infection in dogs in this country.

Keywords: Dermacentor reticulatus, Tick, Babesia canis, Protozoa, Dog, Italy

\footnotetext{
* Correspondence: mariateresa.manfredi@unimi.it

${ }^{2}$ Department of Veterinary Medicine, University of Milan, 20133 Milan, Italy

Full list of author information is available at the end of the article
} 


\section{Background}

The tick species most frequently found on dogs in Europe is Ixodes ricinus in central and southern Europe, Rhipicephalus sanguineus (sensu lato) (s.l.) in countries on the Mediterranean basin and Dermacentor reticulatus in north-central and eastern Europe [1-3]. Further, in eastern Europe the dominance in dogs of Rhipicephalus rossicus was demonstrated whereas in northern Europe Ixodes hexagonus was one of the most common tick of dogs $[4,5]$.

The distribution of tick-borne pathogens often overlaps that of their tick vectors; even if the presence of a potential tick vector does not imply the presence of the transmitted pathogen, tick distribution is indicative for the risk of infection to receptive hosts and for setting control strategies against tick-borne diseases (TBDs), at individual and population level [6]. Dermacentor reticulatus, the "ornate dog tick" or the "marsh tick", is a Palaearctic species with an ecologically limited and mosaic distribution pattern mostly associated to cold and wet sites, as well as to host availability [7, 8]. Immature stages are commonly found on small mammals, with a strong preference for the bank vole (Myodes glareolus), whereas the adults infest large ungulates, carnivores, horses and wild boars [8-11]. The typical biotope of $D$. reticulatus is represented by forest paths and lakeshore vegetation in association with river basins and swampy mixed woods (i.e. Querceto populetum, Populetum mixtum, Saliceto-Populetum) and shrub pasture communities [8]. The geographical distribution of D. reticulatus spans from southwestern England to Central Asia and it recently expanding in many countries, such as Germany, Poland, Hungary, Slovakia, Netherlands and Belgium [7, 12-15], but not occurring in the Mediterranean climatic zone [16]. Amongst others, D. reticulatus may transmit Babesia canis, B. caballi, Theileria equi, Francisella tularensis, Anaplasma phagocytophilum, Coxiella spp., Rickettsia spp. and some tick-borne encephalitis viruses [7]. Canine babesiosis by B. canis is primarily focally distributed in central Europe, whereas in the Mediterranean basin it is mainly caused by Babesia vogeli, where it is associated with the distribution of $R$. sanguineus (s.l.). In northern Italy, a few data support the hypothesis that $B$. canis infection could have an endemic occurrence [17-19]. Following the sole report of $D$. reticulatus in Italy [20], this tick species has never been reported again in this country and $B$. canis was detected only molecularly in a few animals from central and northern Italy $[17,21]$.

Based on the occurrence of two clustered clinical cases of canine babesiosis in two areas of northeastern Italy (Lombardy region) referred by veterinary practitioners and confirmed by serological tests, a study was planned in order to (i) determine the seroprevalence of babesial infection in dogs; (ii) investigate by molecular tools the etiological agents involved in the cases of canine babesiosis; and (iii) identify the potential tick vector of Babesia spp.

\section{Methods}

\section{Study area}

The study area is represented by two parks both located in the eastern part of the Lombardy region (northeastern Italy; $45^{\circ} 34^{\prime} 37.87^{\prime \prime N}, 9^{\circ} 5^{\prime} 3.96 " \mathrm{E}$ ) (Fig. 1). Groane Regional Park (Site A) covers 3,400 ha mainly in the northwest of the province of Milan and includes 17 municipalities distributed between two provinces (Milan and Monza Brianza). The environment is characterised by the presence of several rivers and ponds and largely covered by forest with a dominance of Quercus peduncolata, Q. sessiliflora, Carpinus betulus, Pinus silvestris and Robinia pseudoacacia. The area is characterised by a sub-oceanic climate, with a mean temperature of $12.4{ }^{\circ} \mathrm{C}$, and an annual rainfall of $1,000 \mathrm{~mm}$ (ARPA, http://www.arpalombardia.it/arpa_splash/splash.asp).

The Ticino Valley Lombard Park (Site B) covers 91,000 hectares disseminated along the homonymous river extending between Lake Maggiore and River Po in the western part of Milan province and includes 47 municipalities distributed among three provinces (Milan, Pavia and Varese). Site B presents a wide variety of habitats, including wetlands, watercourses, woods, rice paddies and water meadows. A broad diversity of spontaneous vegetation, due to different ecological conditions is present including tree and shrub species (e.g. Quercus robur, Q. pubescens, Q. petraea, Carpinus betulus, Populus nigra, P. alba, Salix sp., Alnus glutinosa, Corylus avellana, Acer campestre and Crataegus monogyna). The climate of Site B has a typically continental pattern, with a mean temperature of approximately $13{ }^{\circ} \mathrm{C}$ and an annual rainfall of $959 \mathrm{~mm}$ (ARPA, http://www.arpalombardia.it/arpa_splash/splash.asp). Both sites are inhabited by a variety of wildlife species, including the red squirrel (Sciurus vulgaris), weasel (Mustela putorius) and red fox (Vulpes vulpes). The roe deer (Capreolus capreolus) was recently reintroduced into the Site $B$. The presence of a range of wild birds and reptiles has also been reported (http://www.parcogroane.it, [22]).

\section{Tick collection and animal blood sampling procedures}

From March to May 2015 ticks were collected with a woollen blanket $(100 \times 90 \mathrm{~cm})$ using both dragging and flagging techniques, on the ground and the bushes in both areas, respectively. Tick collection was performed in three transects in each park, chosen for being compatible with habitat potentially infested by ticks and for the constant presence of pounds or river basins (Fig. 2). In Site A, ticks were specifically collected in a marked 


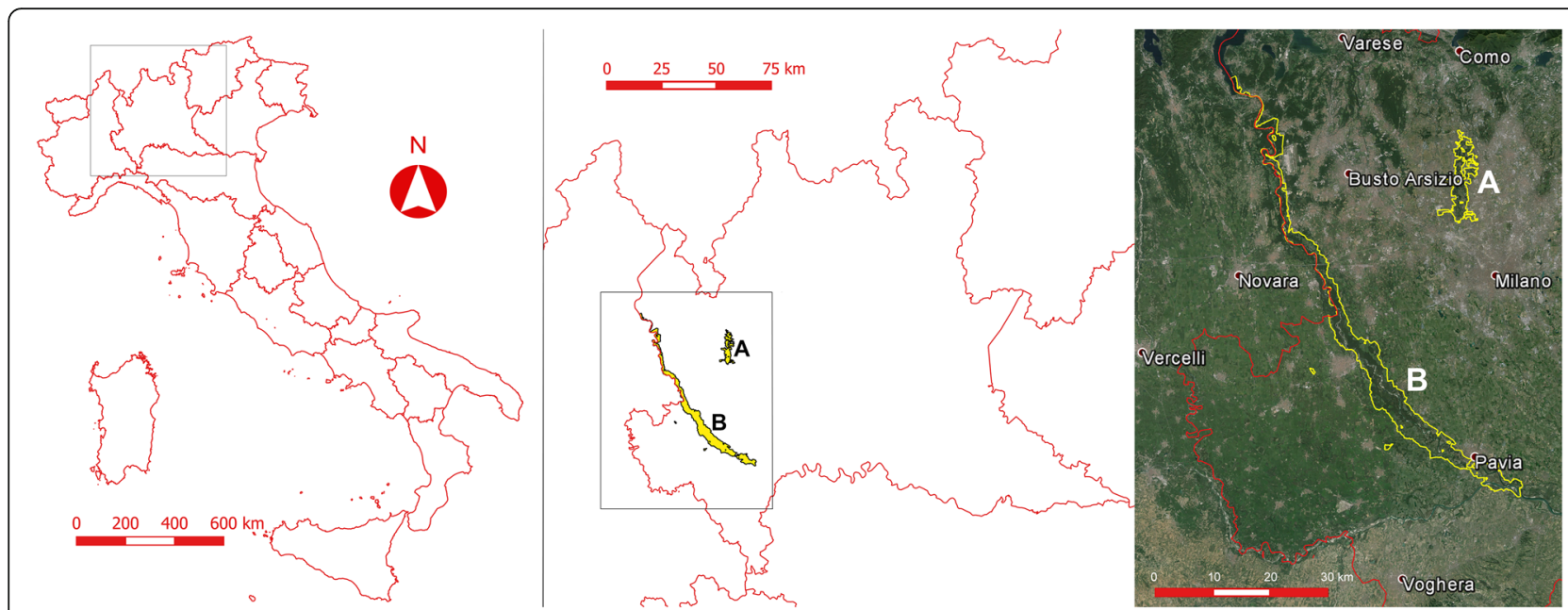

Fig. 1 Map of location of the two study areasGroane Regional Park (Site A) (a) and the Ticino Valley Lombard Park (Site B) (b) in Lombardy (northeastern Italy)

trail for pedestrian with picnic site, closer to human inhabited area $\left(45^{\circ} 38^{\prime} 15.5^{\prime \prime} \mathrm{N}, 9^{\circ} 5^{\prime} 31.69^{\prime \prime} \mathrm{E}\right)$ (Fig. 2, Ai), a bike trail near a recreational sites $\left(45^{\circ} 37^{\prime} 46.5^{\prime \prime} \mathrm{N}, 9^{\circ} 5^{\prime} 53.7^{\prime \prime} \mathrm{E}\right)$ (Fig. 2, Aii) and a dog training camp $\left(45^{\circ} 37^{\prime} 20.9^{\prime \prime} \mathrm{N}, 9^{\circ} 5^{\prime} 34.6^{\prime \prime} \mathrm{E}\right)$ (Fig. 2, Aiii). In Site B collections were conducted in a marked trail near a farm $\left(45^{\circ} 19^{\prime} 39.2^{\prime \prime} \mathrm{N}, 8^{\circ} 55^{\prime} 26.3^{\prime \prime} \mathrm{E}\right)$ (Fig. 2, Bi), a marked trail near a house $\left(45^{\circ} 20^{\prime} 28.01^{\prime \prime} \mathrm{N}, 8^{\circ}\right.$ $55^{\prime 2} 21.9$ "E) (Fig. 2, Bii) and an isolated wood within agricultural field, next to a country road $\left(45^{\circ} 19^{\prime} 57^{\prime \prime} \mathrm{N}, 8^{\circ} 56^{\prime} 2.7^{\prime \prime} \mathrm{E}\right)$ (Fig. 2, Biii). Each sampling session was performed by two

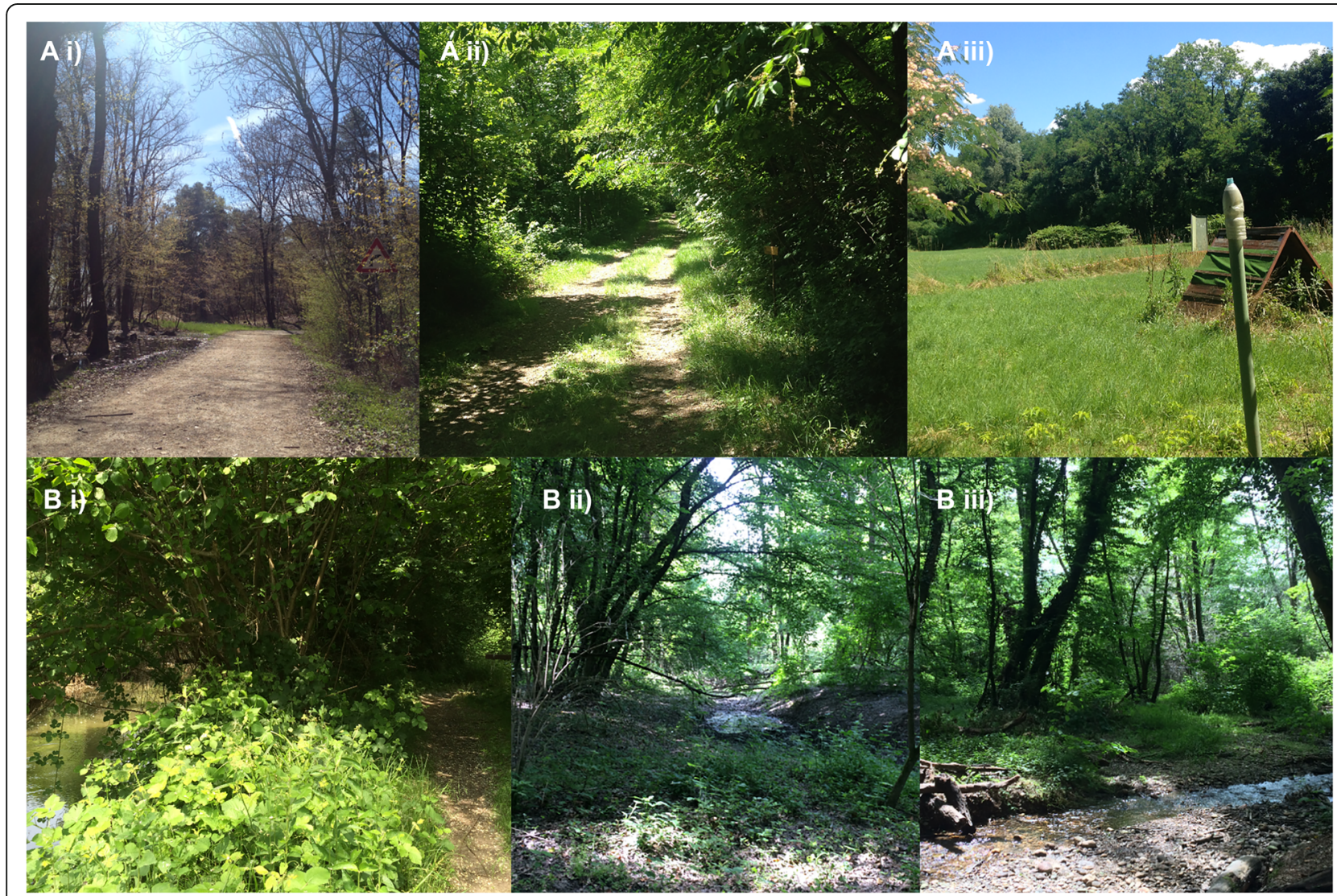

Fig. 2 Collection sites of ticks in Groane Regional Park (Site A) and the Ticino Valley Lombard Park (Site B). SiteA (top): Ai)marked trail, Aii) bike trail, Aiii) dog training camp; Site B (bottom): Bi) marked trail, Bii) marked trail, Biii) isolated wood 
operators along a $100 \mathrm{~m}$ straight transect. The blanket was inspected every 2 metres, the ticks attached were collected using tweezers and placed in vials containing $70 \%$ ethanol. All sampling sessions started in late morning (11 am) and were carried out during sunny days.

In the same period, blood samples were collected from 80 dogs randomly chosen from veterinary clinics and kennel located in the two studied areas, during routine pre-operatory screenings with the owner's consent. Sample size (i.e. 34.5 animals) was defined according to Daniel [23], based on an expected prevalence of $10 \%$, a $95 \%$ confidence interval and a precision of $10 \%$. Therefore, a sample of 40 dogs was established in each study area but the consent was asked to $70 \mathrm{dog}$ owners in each area assuming a high level of refusal. A questionnaire provides data on individual information on life conditions (owned/stray), age (young/adult), lifestyle (indoor/outdoor), gender (male/female) and breed (pure breed/mixed) of dogs. Further, information of travel history, medical history, antiparasitic treatment and testing for vector-borne infections, was collected. Anamnestic data about enrolled dogs for this study reported no travel history abroad, in European areas endemic for babesiosis, or in other Italian regions. No tick infections were detected at the time of sampling and only two dogs had a precedent exposure to ticks. The whole blood samples obtained from the cephalic vein were stored in sterile tubes and then preserved at $+4{ }^{\circ} \mathrm{C}$ for a maximum of 3 days or immediately centrifuged at $1500 \mathrm{~g}$ for $10 \mathrm{~min}$ to obtain serum. Serum and whole blood samples were stored at $-20^{\circ} \mathrm{C}$ until tested.

\section{Morphological and molecular identification of ticks}

Morphological identification of ticks was performed by using taxonomic keys [2, 24, 25]. After morphological identification, six tick specimens (three males and three females) were selected for genetic studies. Genomic DNA extraction was performed using a commercial kit (DNeasy Blood \& Tissue Kit, Qiagen GmbH, Hilden, Germany), in accordance with the manufacturer's instructions. Tick specimens were molecularly characterised by the amplification and sequencing of partial mitochondrial 12S rRNA, 16S rRNA and cytochrome $c$ oxidase subunit 1 (cox 1$)$ genes $(\sim 400,300$ and $600 \mathrm{bp}$, respectively) as previously described [26]. The percentage of nucleotide variation (Pwc, \%) amongst haplotypes, was calculated using the Kimura 2 Parameter substitution model with Gamma Distributed $(\Gamma)$ rates among sites [27], implemented in the MEGA6 software [28].

For phylogenetic analyses, sequences herein obtained for all genes and those available from the GenBank database for other Dermacentor spp. were included. The phylogenetic relationships were inferred by Maximum Likelihood (ML) [27] analysis, conducted using the General Time
Reversible (GTR) model using MEGA6 software for both genes [28]. For each gene, homologous sequences for $R$. sanguineus (s.l.) (accession numbers: 12S rRNA gene KC243790; 16S rRNA gene KC243837; cox1 KC243880) were used as outgroup.

\section{Serology by IFAT procedure}

Dog serum samples were tested with a commercial indirect fluorescent antibody test (IFAT) (MegaScreen ${ }^{\circ} \mathrm{FLUO}$ Babesia canis, MegaCor Diagnostic, Horbranz, Austria) to detect the presence of IgG antibodies against B. canis, using canine erythrocytes infected with $B$. canis as antigens. Positive and negative controls were always included and were provided by the company. Starting, sera were initially diluted 1:64 in phosphate-buffered saline solution (PBS) $(\mathrm{pH}=7.2)$, applied to slide wells and incubated in a moist chamber for $30 \mathrm{~min}$ a $37^{\circ} \mathrm{C}$. The slides were washed and reacted with fluorescein isothiocyanate-conjugated rabbit anti-Dog IgG (Sigma-Aldrich, Milan, Italy), incubated at $37{ }^{\circ} \mathrm{C}$ in a humid chamber for $30 \mathrm{~min}$. The slides were mounted with buffered glycerin and covered with a coverslip. Finally, the slides were examined with a microscope (Axioscop 2, Zeiss) under a fluorescent light (HBO50). Those samples that had fluorescence at a diluition $\geq 1: 64$ were considered as seropositive. Samples resulting seropositive were then diluted to determine the end-point titre (i.e. the last dilution in which is observed positive reaction).

\section{PCR amplification and DNA sequencing of Babesia spp.} from ticks and dog whole-blood samples

For the detection Babesia spp., genomic DNA was extracted from $100 \mu \mathrm{l}$ of whole-blood samples using the Archive Pure DNA Blood Kit (5-Prime, GmBh, Hamburg, Germany). Ticks and blood samples were tested by PCR amplification using primers targeting the $18 \mathrm{~S}$ rRNA gene of Babesia spp. ( $410 \mathrm{bp})$ following previously published methodologies and amplification protocols [29]. A positive control containing genomic $B$. canis DNA and a negative control without DNA were also included. All PCR products were examined on $2 \%$ agarose gels stained with GelRed (VWR International PBI, Milan, Italy) and visualised on a GelLogic 100 gel documentation system (Kodak, New York, USA). The amplicons were purified and sequenced, in both directions using the PCR primers, employing the Taq Dye Deoxy Terminator Cycle Sequencing Kit (v.2, Applied Biosystems, Monza MB, Italy) on an automated sequencer (ABI-PRISM 377). Sequences were aligned using ClustalW programme [30] and compared with those available in the GenBank database (BLAST,http://blast.ncbi.nlm.nih.gov/Blast.cgi).

\section{Results}

All ticks collected in the surveyed areas $(n=34)$ were morphologically identified as adults of $D$. reticulatus. 
Briefly, adult specimens of $D$. reticulatus were differentiated by the presence of a spur on the dorsal surface, extending posteriorly, of the second palp articles, a bifid coxa, with coxal spurs in coxa I not divergent, spiracle plates comma-shaped with a small dorsal apofisa. In males, cornua (external margins of the posterior dorsal surface of basis capituli) were prominent and rounded apically, scutum had broad lateral grooves with several small punctations, trochanter 1 bearing a long dorsal posterior spur. Female D. reticulatus had oval shaped porose areas on the dorsal surface of the basis capituli, the ornate scutum had sides rather rounded and not particularly angular, the genital aperture lacked wing-like outgrowths and formed a broad U shape, truncated posteriorly, anal groove surrounding anus posteriorly and continued in a posterior post anal groove.

Of the 34 adult $D$. reticulatus collected from the ground of both surveyed areas, 28 (13 males and 15 females) were found in all transects from Site A and the remaining six specimens (three males and three females) were collected in Site B in two out of three settled transects. Ticks were collected in May $(n=19 ; 56 \%)$, April $(n=9 ; 26 \%)$ and March $(n=6 ; 18 \%)$. Blast analysis of all mitochondrial sequences confirmed the morphological identification of the tick specimens processed by revealing a highest sequence nucleotide similarity (99-100 \%) with those of D. reticulatus available from GenBank (i.e. 12S rRNA gene: JQ768760; 16S rRNA gene: JF928523; and cox1: AF132829). The obtained sequences were deposited in GenBank (accession numbers: KX018990-KX018994). For cox1, three haplotypes were identified, with a nucleotide variation of up to $0.4 \%$. The conceptual translation at second codon position of cox 1 haplotypes resulted in amino acid sequences with no stop codons. The vast majority of nucleotide substitutions were synonymous substitutions $(\mathrm{d} S)$, with the exception of one (second codon position; non-synonymous substitutions $\mathrm{dN}$ ), which resulted in amino acid alterations (Val-Met). Reflecting the molecular identification, the phylogenetic trees of haplotypes for all genes herein examined and those for other Dermacentor spp. retrieved from GenBank, were concordant in clustering D. reticulatus in a monophyletic clade with the exclusion of other ticks species (Fig. 3).

A total of seven dogs $(8.8 \%)$ had antibodies against $B$. canis, most of which came from Site A (Table 1). Out of the seven dogs, five $(6.3 \%)$ and two $(2.5 \%)$ were positive at high titres of 1:1.024 and 1:512, respectively. The highest seroprevalence values were observed in May $(n=4 ; 57 \%)$ and April $(n=2 ; 29 \%)$. Information on positive dogs is summarised in Table 1; all of them were owned, none of them had been travelling 12 months prior to sample collection and they had never been in endemic region for B. canis infection. Further, none of the sampled dogs had a vaccination for Babesia. Babesia spp. DNA was amplified from four out of six ticks processed molecularly, and from three (i.e. two from Site B and one from Site A) out of 80 tested canine whole blood samples (Table 2). Analysis of nucleotide sequences obtained from ticks and from one dog identified with B. canis displayed $100 \%$ similarity to that available in GenBank (DQ174284.1).

\section{Discussion}

This study morphologically and molecularly confirms previous sporadic reports of $D$. reticulatus in Italy $[20,31]$ and links, for the first time, its presence with the occurrence of $B$. canis infection in dogs in this country. Our data represent one of the southernmost findings of $D$. reticulatus in Europe, which is usually reported in Switzerland [32], France [33, 34], Austria [35], Croatia [36] and Slovenia [37]. In addition, since a few specimens of $D$. reticulatus have been so far collected below the limit of $50^{\circ} \mathrm{N}$ (e.g. in Portugal, Romania and Hungary [7]) data here presented confirm that this tick species may occur even below the $45^{\circ} \mathrm{N}$ perpetuating its biological life-cycle in regions of the Mediterranean basin, where meteorological conditions compatible with tick requirements occur (e.g. spring precipitation of 400$1000 \mathrm{~mm}$ and a summer isotherm of $20-22{ }^{\circ} \mathrm{C}$ ) [38].

The environment of both parks, in the area of low plain of Po Valley, is suitable for the life-cycle of D. reticulatus, since they are characterised by clay, loam and rich of waters of different origins, consistent with the typical biotope of this tick species [7, 8]. Moreover, by the end of 1800 's through the 1950's, at the time when this territory was mostly characterised by swampy lands, paddies and water-meadows continuously irrigate to allow the growth of grass also in the cold winter, this tick species might have been even more widespread compared to the present. In the past decades, the extensive changes of the territory, as well as the strong reduction of water-meadows replaced by intensive agricultural practices mainly aimed to produce cereals and the increase of urbanisation occurred in that area may have reduced the suitable areas for $D$. reticulatus that are waste lands [7, 39]. Moreover, the wetland environments of the surveyed parks are preserved by the European rules (Dir. 79/409/CEE) and both parks are rich of animal species that could act as potential suitable hosts (e.g. dogs, horses, cattle, wild ungulates and the bank vole). Dermacentor reticulatus were collected in rural areas close to urban settings hence confirming previous findings of this tick species proliferating in waste lands situated between the blocks of apartments of large residential estates where it was supported by the increase of canine population in the areas [39] and even in towns [7], emphasising the sanitary risks for human beings [6]. 

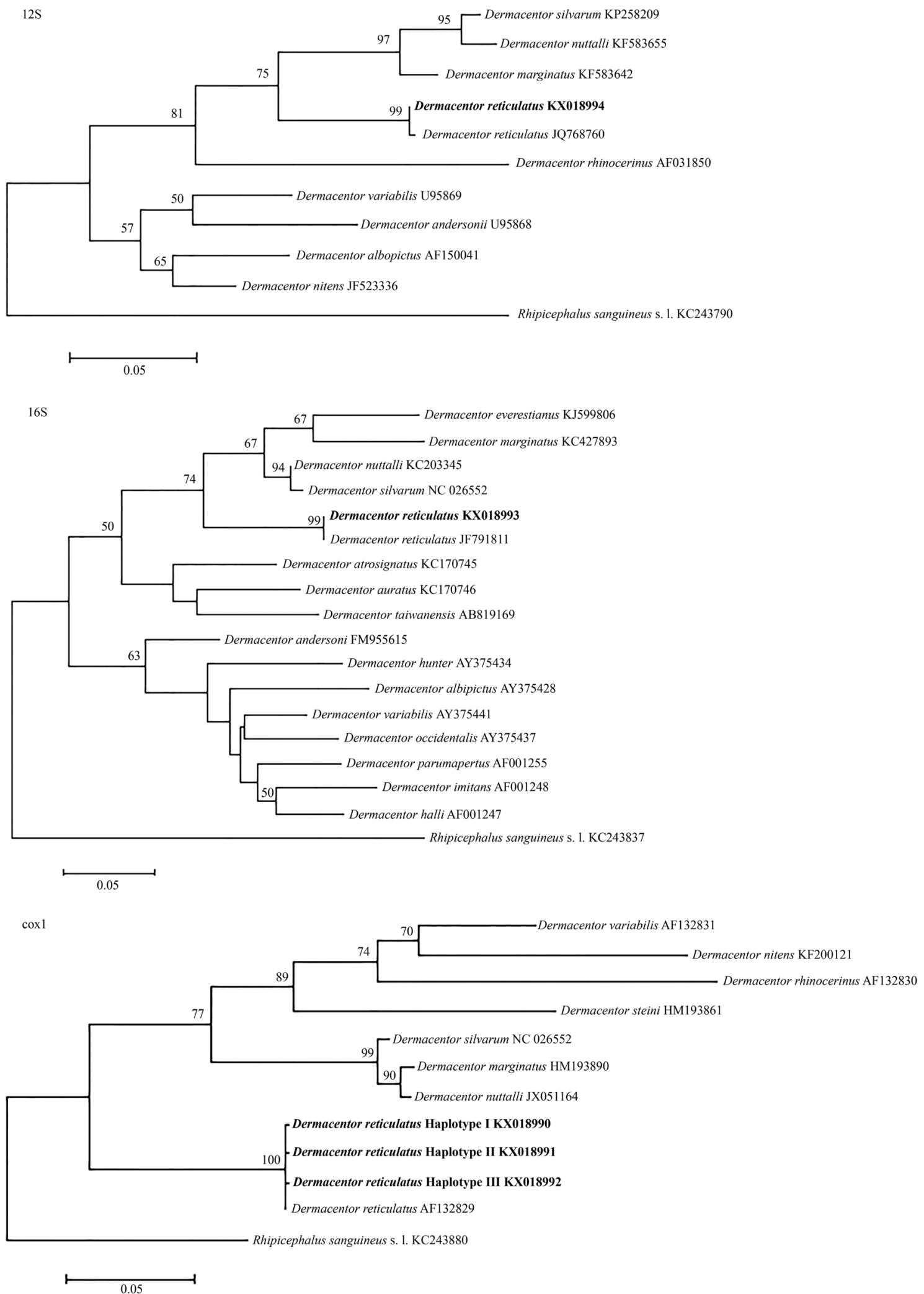

Fig. 3 Phylogenetic trees for Dermacentor spp. including the newly-sequenced isolates of Dermacentor reticulatus (bold) and sequences from other species available in the GenBank database. Nodal support bootstrap values > $50 \%$ are indicated only. Rhipicephalus sanguineus (sensu lato) was used as the outgroup 
Table 1 Summarised details of ten dogs resulted positive for Babesia canis at IFAT or PCR

\begin{tabular}{|c|c|c|c|c|c|c|c|}
\hline Dog-ID & Sex ${ }^{a}$ & Age (months) & Breed & Clinical signs & Site $^{b}$ & $P C R$ & IFAT \\
\hline 1 & M & 120 & Mixed & none & A & Negative & $1 / 1024$ \\
\hline 2 & M & 108 & Mixed & hemoglobinuria & A & Negative & $1 / 1024$ \\
\hline 3 & M & 60 & Mixed & none & A & Negative & $1 / 1024$ \\
\hline 4 & M & 48 & Mixed & none & $A$ & Negative & $1 / 512$ \\
\hline 5 & $\mathrm{~F}$ & 72 & Mixed & none & A & Negative & $1 / 1024$ \\
\hline 6 & F & 12 & Mixed & none & B & Positive & Negative \\
\hline 7 & $\mathrm{~F}$ & 108 & Italian griffon & none & B & Positive & Negative \\
\hline 8 & $\mathrm{~F}$ & 12 & Mixed & none & B & Negative & $1 / 512$ \\
\hline 9 & M & 72 & Chow chow & weaknessfever & A & Positive & Negative \\
\hline 10 & M & 84 & Hovawart & None & A & Negative & $1 / 1024$ \\
\hline
\end{tabular}

${ }^{\mathrm{a} S e x:} \mathrm{F}$, female; $M$, male

${ }^{\mathrm{b}}$ Site A: Groane Regional Park; Site B: Ticino Valley Lombard Park; IFAT: serum titre

Dermacentor reticulatus is exo-endophilic (adult ticks occur on the vegetation whereas immature ticks are associated with nests), ditropic (immature and adult ticks feed on different host species), and three-host (each life-cycle stage requires a new host to feed on) tick species, being the adult stages usually associated with large mammals (horses, cattle, dogs and wild ungulates) and the juvenile stages with several species of micro-mammals $[2,40]$. In the surveyed areas this tick species was most likely associated with dogs (horses and cattle are confined in stables and in farms) though wild ungulates, such as the roe deer (Capreolus capreolus), transit in the Ticino Valley Lombard Park, which is known as an ecological corridor for this wild species. In addition, in both collection sites the bank vole (Myodes glareolus), which is the favourite host for the immature stage of $D$. reticulatus, is highly prevalent [9].

The number of ticks collected in the surveyed areas is consistent with the findings of other surveys carried out in neighboring countries with similar ecological and host features, but is lower than that of $D$. reticulatus in the western and eastern Europe [32].

The seroprevalence of B. canis here detected ( $8.8 \%)$, also confirmed by molecular tests and gene sequencing of the pathogen, was lower than that previously reported in northeastern, central and southern Italy (i.e. 70 \%; see $[21,41])$. Such, a prevalence of infection of $B$. canis in southern Italy most likely indicates the failure of serological tests in differentiating anti-B. canis and B. vogeli specific antibodies $[42,43]$. Although in previous studies the occurrence of ticks on hosts has never been investigated thoroughly $[21,41]$, it is known that $R$. sanguineus (s.l.), the vector of $B$. vogeli, is the most frequently retrieved tick species but not $D$. reticulatus $[20,44]$.

Whether B. canis has been recently introduced in the studied area or it is present since along time is difficult to be assessed. Nonetheless, the studied area is historically known as endemic for canine babesiosis. Indeed, Piana \& Galli-Valerio [45] firstly described Babesia sp. infection in a hunting dog in the first week of April from an adjacent area of Ticino Valley Lombard Park. The low seroprevalence actually recorded in the studied area may also be the consequence of a reduction of tick infestations on dogs due to the increase of awareness and education of owner and veterinary practitioners, along with the increase of use of acaricide products among the prophylactic measures in dogs $[46,47]$.

The IFAT positivity here detected was uncorrelated with PCR results due to the fact that after the decrease of parasitemia, antibodies are still present [21]. However,

Table 2 Results of Babesia canis tests on dog samples and ticks from two surveyed areas in northeastern Italy

\begin{tabular}{|c|c|c|c|c|c|c|c|c|c|}
\hline \multirow[t]{4}{*}{ Samples } & \multicolumn{4}{|l|}{ Site A } & \multicolumn{4}{|l|}{ Site B } & \multirow[t]{3}{*}{ Both sites } \\
\hline & \multirow[t]{2}{*}{ IFAT } & \multicolumn{2}{|l|}{ PCR } & \multirow[t]{2}{*}{ Total } & \multirow[t]{2}{*}{ IFAT } & \multicolumn{2}{|l|}{ PCR } & \multirow[t]{2}{*}{ Total } & \\
\hline & & Positive & $\begin{array}{l}\text { B. canis } \\
\text { confirmatory } \\
\text { sequencing }\end{array}$ & & & Positive & $\begin{array}{l}\text { B. canis } \\
\text { confirmatory } \\
\text { sequencing }\end{array}$ & & \\
\hline & N/tested ${ }^{\mathrm{a}}(\%)$ & N/tested ${ }^{a}(\%)$ & $\mathrm{N} /$ tested $^{\mathrm{a}}(\%)$ & N/tested ${ }^{a}(\%)$ & N/tested ${ }^{a}(\%)$ & $\mathrm{N} /$ tested $^{\mathrm{a}}(\%)$ & N/tested ${ }^{\mathrm{a}}(\%)$ & N/tested ${ }^{\mathrm{a}}(\%)$ & N/tested ${ }^{\mathrm{a}}(\%)$ \\
\hline $\operatorname{Dogs}^{b}$ & $6 / 57(10.5)$ & $1 / 57(1.7)$ & $1 / 1(100)$ & $7 / 57(12.3)$ & $1 / 23(4.3)$ & $2 / 23(8.7)$ & - & $3 / 23(13.1)$ & $10 / 80(8.0)$ \\
\hline Ticks & - & $3 / 3(100)$ & $1 / 3(33.0)$ & $3 / 3(100)$ & - & 1/3(33.0) & - & 1/3(33.0) & $4 / 6(66.7)$ \\
\hline
\end{tabular}

${ }^{\mathrm{a}} \mathrm{N} /$ tested $=$ number of positive samples/number of tested samples

${ }^{\mathrm{b}} \mathrm{Sera}$ or whole-blood samples 
the molecular detection of $B$. canis in natural infected dogs and, for the first time in Italy, in questing $D$. reticulatus confirms the focal nature of the infection. Recently, B. canis was molecularly characterised in two out of three Dermacentor marginatus (but not D. reticulatus), morphologically identified, from dogs in northern Italy [48], hence raising some doubts on the morphological characterisation of those tick species that is associated to wild and domestic ungulates, and only seldom to dogs and humans $[2,24,25]$. Considering also that D. marginatus should not be the competent vector for $B$. canis being that to the best of our knowledge, no data are available to simultaneously demonstrate the molecular identification of both $D$. marginatus and $B$. canis, then $D$. reticulatus and consequently $B$. canis may occur in other areas of Italy, outside the surveyed foci.

Finally, the nucleotide identity of $B$. canis from dogs and ticks indicates that the same strain circulates in the studied area among vectors and definitive hosts. The endemic nature of canine babesiosis by $B$. canis has been previously described in Germany [49], Croatia [50], Slovenia [51], Hungary [52], Russia [53], Spain [54], Portugal [55], Albania [56], Slovakia [57], Serbia [58], Switzerland [32], Netherlands and Belgium [14], Poland [59] and France [34].

The occurrence of $D$. reticulatus in sites from two parks of northeastern Italy located in a highly urbanised area indicates that risk factors linked to $B$. canis in dogs are not confined to hunting dogs as in the past [60], but infections also reaches owned dogs living in small urban centres included in or close to natural environments.

\section{Conclusion}

This study demonstrates that B. canis and its vector, $D$. reticulatus ticks, circulate in northeastern Italy. Although $D$. reticulatus only seldom bites humans, its capacity as a vector of zoonotic pathogens (e.g. Rickettsia slovaca, $R$ raoultii and $R$. helvetica) sounds as an alarm bell for physicians working in areas where this tick species may occur.

\section{Competing interests}

The authors declare that they have no competing interests.

\section{Authors' contributions}

EO, SAZ, DO and MTM conceived and designed the experiments. EO and SAZ performed the sample collection. EO, MSL, SAZ and RPL performed the laboratorial analysis. EO, SAZ, DO and MTM wrote the first draft. FDT contributed to the intellectual contents and inputs of the article. All authors read and approved the final manuscript.

\section{Author details}

${ }^{1}$ Department of Veterinary Medicine, University of Perugia, 06126 Perugia, Italy. ${ }^{2}$ Department of Veterinary Medicine, University of Milan, 20133 Milan, Italy. ${ }^{3}$ Department of Veterinary Medicine, University of Bari, 70010 Valenzano, Bari, Italy. ${ }^{4}$ Department of Immunology, Aggeu Magalhães Research Centre Oswaldo Cruz Foundation (Fiocruz), 50740465 Recife, Pernambuco, Brazil.
Received: 13 January 2016 Accepted: 10 April 2016

Published online: 18 April 2016

\section{References}

1. Genchi C, Manfredi MT. Tick species infesting ruminants in Italy: ecological and bio-climatic factors affecting the different regional distribution. Parassitologia. 1999;41:41-5.

2. Estrada-Peña A, Bouattour A, Camicas J, Horak I, Latif A, Pegram R, et al. Ticks of domestic animals in Mediterranean Region: a guide to identification of species. 1st ed. Zaragoza: University of Zaragoza; 2004.

3. Beugnet $F$, Marié JL. Emerging arthropod-borne diseases of companion animals in Europe. Vet Parasitol. 2009;163:298-305.

4. Ogden NH, Cripps P, Davison CC, Owen G, Parry JM, Timms BJ, et al. The ixodid tick species attaching to domestic dogs and cats in Great Britain and Ireland. Med Vet Entomol. 2000;14:332-8.

5. Sándor AD, Dumitrache MO, D'Amico G, Kiss BJ, Mihalca AD. Rhipicephalus rossicus and not $R$. sanguineus is the dominant tick species of dogs in the wetlands of the Danube Delta, Romania. Vet Parasitol. 2014;204:430-2.

6. Dantas-Torres F, Otranto D. Best practices for preventing vector-borne diseases in dogs and humans. Trends Parasitol. 2015:32:43-55.

7. Karbowiak G. The occurrence of the Dermacentor reticulatus tick-its expansion to new areas and possible causes. Ann Parasitol. 2014;60:37-47.

8. Nosek J. The ecology and public health importance of Dermacentor marginatus and D. reticulatus ticks in Central Europe. Folia Parasitol. 1972;19:93-102

9. Pfäffle M, Littwin N, Petney T. Host preferences of immature Dermacentor reticulatus (Acari: Ixodidae) in a forest habitat in Germany. Ticks Tick Borne Dis. 2015;6:508-15.

10. Mierzejewska EJ, Pawełczyk A, Radkowski M, Welc-Falęciak R, Bajer A. Pathogens vectored by the tick, Dermacentor reticulatus, in endemic regions and zones of expansion in Poland. Parasit Vectors. 2015;8:490.

11. Mierzejewska EJ, Welc-Faleciak R, Karbowiak G, Kowalec M, Behnke JM, Bajer A. Dominance of Dermacentor reticulatus over Ixodes ricinus (Ixodidae) on livestock, companion animals and wild ruminants in eastern and central Poland. Exp Appl Acarol. 2015:66:83-101.

12. Dautel H, Dippel C, Oehme R, Hartelt K, Schettler E. Evidence for an increased geographical distribution of Dermacentor reticulatus in Germany and detection of Rickettsia sp. RpA4. Int J Med Microbiol. 2006;296(40):149-56.

13. Bullová E, Lukán M, Stanko M, Petko B. Spatial distribution of Dermacentor reticulatus tick in Slovakia in the beginning of the 21 st century. Vet Parasitol. 2009;165:357-60.

14. Jongejan F, Ringenier M, Putting M, Berger L, Burgers S, Kortekaas R, et al. Novel foci of Dermacentor reticulatus ticks infected with Babesia canis and Babesia caballi in the Netherlands and in Belgium. Parasit Vectors. 2015;8:232.

15. Mierzejewska EJ, Estrada-Peña A, Alsarraf M, Kowalec M, Bajer A. Mapping of Dermacentor reticulatus expansion in Poland in 2012-2014. Ticks Tick Borne Dis. 2015;7:94-106.

16. Rubel F, Brugger $K$, Pfeffer $M$, Chitimia-Dobler $L$, Didyk YM, Leverenz $S$, et al Geographical distribution of Dermacentor marginatus and Dermacentor reticulatus in Europe. Ticks Tick Borne Dis. 2016;224-233.

17. Solano-Gallego L, Trotta M, Carlia E, Carcy B, Caldina M, Furlanello T. Babesia canis canis and Babesia canis vogeli clinicopathological findings and DNA detection by means of PCR-RFLP in blood from Italian dogs suspected of tick-borne disease. Vet Parasitol. 2008;157:211-21.

18. Otranto D, Dantas-Torres F. Canine and feline vector-borne diseases in Italy: current situation and perspectives. Parasit Vectors. 2010;3:2.

19. Halos L, Lebert I, Abrial D, Danlois F, Garzik K, Rodes D, et al. Questionnairebased survey on the distribution and incidence of canine babesiosis in countries of Western Europe. Parasite. 2014;21:13.

20. Manfredi MT. Dermacentor reticulatus Fabricius 1794 nel cane in Italia. Atti Soc Ital Sci Vet. 1995:49:759-60.

21. Cassini R, Zanutto S. Frangipane di Regalbono A, Gabrielli S, Calderini P, Moretti A, et al. Canine piroplasmosis in Italy: epidemiological aspects in vertebrate and invertebrate hosts. Vet Parasitol. 2009:165:30-5.

22. Gariboldi L. Atlante delle flora. I Quaderni del Parco delle Groane. 1st ed. Milan: Consorzio Parco delle Groane; 2008.

23. Daniel WW. Biostatistics: A foundation for analysis in the health sciences. 7th ed. New York: John Wiley \& Sons; 1999.

24. Arthur DR. Ticks and disease. 1st ed. Oxford: Pergamon Press; 1962. 
25. Pomerantzev BI. Fauna of USSR. Arachnida. Vol. IV. Ixodid Ticks (Ixodidae). 2nd ed. Pankobraznye: Moscow; 1950.

26. Latrofa MS, Dantas-Torres F, Annoscia G, Cantacessi C, Otranto D. Comparative analyses of mitochondrial and nuclear genetic markers for the molecular identification of Rhipicephalus spp. Infect Genet Evol. 2013;20:422-7.

27. Kimura M. A simple method for estimating evolutionary rates of base substitutions through comparative studies of nucleotide sequences. J Mol Evol. 1980:16:111-20.

28. Tamura K, Stecher G, Peterson D, Filipski A, Kumar S. MEGA6: Molecular evolutionary genetics analysis version 6.0. Mol Biol Evol. 2013:30:2725-9.

29. Olmeda AS, Armstrong PM, Rosenthal BM, Valladares B, Del Castillo A, De Armas F, et al. A subtropical case of human babesiosis. Acta Trop. 1997;67:229-34.

30. Larkin MA, Blackshields G, Brown NP, Chenna R, McGettigan PA, McWilliam $\mathrm{H}$, et al. Clustal W and Clustal X version 2.0. Bioinformatics. 2007;23:2947-8.

31. Iori A, Gabrielli S, Calderini P, Moretti A, Pietrobelli M, Tampieri MP, et al. Tick reservoirs for piroplasms in central and northern Italy. Vet Parasitol. 2010;170:291-6.

32. Schaarschmidt D, Gilli U, Gottstein B, Marreros N, Kuhnert P, Daeppen JA, et al. Questing Dermacentor reticulatus harbouring Babesia canis DNA associated with outbreaks of canine babesiosis in the Swiss Midlands. Ticks Tick Borne Dis. 2013;4:334-40

33. Bonnet S, de la Fuente J, Nicollet P, Liu X, Madani N, Blanchard B, et al. Prevalence of tick-borne pathogens in adult Dermacentor spp. ticks from nine collection sites in France. Vector Borne Zoonotic Dis. 2013:13:226-36.

34. René-Martellet M, Moro CV, Chêne J, Bourdoiseau G, Chabanne L, Mavingui P. Update on epidemiology of canine babesiosis in southern France. BMC Vet Res. 2015;11:223.

35. Hubálek Z, Sixl W, Halouzka J. Francisella tularensis in Dermacentor reticulatus ticks from the Czech Republic and Austria. Wien Klin Wochenschr. 1998;110:909-10

36. Dobec M, Golubic D, Punda-Polic V, Kaeppeli F, Sievers M. Rickettsia helvetica in Dermacentor reticulatus ticks. Emerg Infect Dis. 2009;15:98-100.

37. Duh D, Tozon N, Petrovec M, StraŠek K, AvŠic-Županc T. Canine babesiosis in Slovenia: molecular evidence of Babesia canis canis and Babesia canis vogeli. Vet Res. 2004;35:363-8.

38. Immler RM. Untersuchungen zur Bilogie und Ökologie der Zecke Dermacentor reticulatus (Fabricius, 1794) (Ixodidae) in einem endemischen Vorkommensgebiet. Mitteilungender Schweizerischen Entomologischen Gesellschaft. 1973;46:2-70.

39. Gilot B, Pautou G, Immler R, Moncada E. Suburban biotype of Dermacentor reticulatus (Fabricius, 1794)(Ixodoidea). Preliminary study. Rev Suisse Zool. 1973:80:411-30

40. Drozdz J, Bogdaszewska Z. A focus of Dermacentor reticulatus kept by red and fallow deer in animal husbandry (Kosewo, Poland). Wiad Parazytol. 1996;43:207-12.

41. Pennisi MG, Caprì A, Solano-Gallego L, Lombardo G, Torina A, Masucci M. Prevalence of antibodies against Rickettsia conorii, Babesia canis, Ehrlichia canis, and Anaplasma phagocytophilum antigens in dogs from the Stretto di Messina area (Italy). Ticks Tick Borne Dis. 2012;3:315-8.

42. Boozer AL, Macintire DK. Canine babesiosis. Vet Clin North Am Small Anim Pract. 2003;33:885-904

43. Taylor MA, Coop RL, Wall RL. Parassitologia e Malattie Parassitarie degli Animali. 1st ed. Rome: EMSI; 2010

44. Manfredi MT, Dini V, Piacenza S. Tick infestation in domestic carnivores from north Italy. Parassitologia. 2000;42:203.

45. Piana GP, Galli-Valerio B. Su di un'infezione del cane con parassiti endoglobulari nel sangue. Nota Prev Mod Zooiatro. 1895;6:163-9.

46. Fourie JJ, Stanneck D, Jongejan F. Prevention of transmission of Babesia canis by Dermacentor reticulatus ticks to dogs treated with an imidacloprid/ flumethrin collar. Vet Parasitol. 2013;192:273-8.

47. Navarro C, Reymond N, Fourie J, Hellmann K, Bonneau S. Prevention of Babesia canis in dogs: efficacy of a fixed combination of permethrin and fipronil (Effitix ${ }^{\oplus}$ using an experimental transmission blocking model with infected Dermacentor reticulatus ticks. Parasit Vectors. 2015;8:1-10.

48. Trotta M, Nicetto M, Fogliazza A, Montarsi F, Caldin M, Furlanello T, et al. Detection of Leishmania infantum, Babesia canis, and rickettsiae in ticks removed from dogs living in Italy. Ticks Tick Borne Dis. 2012:3:294-7.

49. Zahler M, Schein E, Rinder H, Gothe R. Characteristic genotypes discriminate between Babesia canis isolates of differing vector specificity and pathogenicity to dogs. Parasitol Res. 1998;84:544-8.
50. Cacciò SM, Antunovic B, Moretti A, Mangili V, Marinculic A, Baric RR, et al. Molecular characterisation of Babesia canis canis and Babesia canis vogeli from naturally infected European dogs. Vet Parasitol. 2002;106:285-92.

51. Duh D, Tozon N, Petrovec M, StraŠek K, AvŠic-Županc T. Canine babesiosis in Slovenia: molecular evidence of Babesia canis canis and Babesia canis vogeli. Vet Res. 2004;35:363-8.

52. Földvári G, Hell E, Farkas R. Babesia canis canis in dogs from Hungary: detection by PCR and sequencing. Vet Parasitol. 2005;127:221-6.

53. Rar VA, Maksimova TG, Zakharenko LP, Bolykhina SA, Dobrotvorsky AK, Morozova OV. Babesia DNA detection in canine blood and Dermacentor reticulatus ticks in southwestern Siberia, Russia. Vector-Borne Zoonotic Dis. 2005;5:285-7.

54. Criado-Fornelio A, Rey-Valeiron C, Buling A, Barba-Carretero JC, Jefferies R, Irwin P. New advances in molecular epizootiology of canine hematic protozoa from Venezuela, Thailand and Spain. Vet Parasitol. 2007:144:261-9.

55. Cardoso L, Costa Á, Tuna J, Vieira L, Eyal O, Yisaschar-Mekuzas Y, et al. Babesia canis canis and Babesia canis vogeli infections in dogs from northern Portugal. Vet Parasitol. 2008;156:199-204.

56. Hamel D, Silaghi C, Knaus M, Visser M, Kusi I, Rapti D, et al. Detection of Babesia canis subspecies and other arthropod-borne diseases in dogs from Tirana, Albania. Wien Klin Wochenschr. 2009;121:42-5.

57. Kubelová M, Tkadlec E, Bednář M, Roubalová E, Široký P. West-to-east differences of Babesia caniscanis prevalence in Dermacentor reticulatus ticks in Slovakia. Vet Parasitol. 2011;180:191-6.

58. Mihaljica D, Radulović Ž, Tomanović S, Ćakić S, Penezić A, Milutinović M. Molecular detection of Babesia spp. in ticks in northern Serbia. Arch Biol Sci. 2012;64:1591-8.

59. Wójcik-Fatla A, Zając V, Sawczyn A, Cisak E, Dutkiewicz J. Babesia spp. in questing ticks from eastern Poland: prevalence and species diversity. Parasitol Res. 2015;114:3111-6.

60. Ebani W, Nardoni S, Fognani G, Mugnaini L, Bertelloni F, Rocchigiani G, et al. Molecular detection of vector-borne bacteria and protozoa in healthy hunting dogs from Central Italy. Asian Pac J Trop Biomed. 2015;5:108-12.

doi:10.1186/s13071-016-1502-9

Cite this article as: Olivieri et al:: The southernmost foci of Dermacentor reticulatus in Italy and associated Babesia canis infection in dogs. Parasites \& Vectors 20168 :.

\section{Submit your next manuscript to BioMed Central and we will help you at every step:}

- We accept pre-submission inquiries

- Our selector tool helps you to find the most relevant journal

- We provide round the clock customer support

- Convenient online submission

- Thorough peer review

- Inclusion in PubMed and all major indexing services

- Maximum visibility for your research

Submit your manuscript at www.biomedcentral.com/submit
Biomed Central 